\title{
Inflation Expectations, Business Taxation And The Incentive To Invest In Depreciable Capital Goods
}

Edmund H. Mantell, Pace University, USA

\begin{abstract}
A parochial issue in business taxation - one which was discussed vigorously during the U.S. 20072009 economic contraction - is the issue of how corporate Federal income tax policy affects incentives for businesses to undertake new investments in capital goods. This paper focuses on the question of how the tax treatment of depreciation affects the incentives of business to invest in capital goods when businesses (rightly or wrongly) expect significant inflation during the depreciable life of the investment. An innovative idea of adjusting the system of tax depreciation for inflation is to allow an immediate deduction for the present value of the future economic depreciation that firms could claim if there were zero inflation. No adjustment for inflation would ever be needed because the depreciation charge would be taken in the same year in which the asset was purchased. The result of this approach is consistent with the result for inflation-adjusted historical cost depreciation because gains from changes in the relative prices of depreciable assets would be included in income.
\end{abstract}

Keywords: Depreciation; Tax Shield; Inflation Expectations; Investments in Capital Goods

\section{INTRODUCTION}

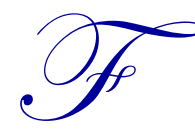

ew issues in public finance generate as much controversy among policy-makers and the business community as the question of the "appropriate" taxation of corporate income. The vigor and the persistence of the controversy arise from two sources:

1. There is disagreement regarding the normative objectives of corporate tax policy; i.e., what objective should tax policy be designed to achieve?

2. Even among those discussants who agree as to the propriety of tax policy objectives, there is divergence of opinion as to the practical means of achieving those objectives.

Results cited by Edgerton (2009) suggest that tax incentives have the smallest impact on investment exactly when they are most likely to be put in place - during downturns in economic activity when cash flows are low. For example, in March 2002, President Bush signed into law the Job Creation and Worker Assistance Act ${ }^{1}$, which included "bonus depreciation" provisions that allowed firms to deduct from their taxable income a larger portion of their spending on new capital equipment. Similar incentives were enacted in response to the recession in 2008 and remained in place through the end of 2009. Bonus depreciation was intended to encourage firms to increase their investments in capital goods, but several observers found it had little effect. ${ }^{2}$ This paper analyzes the reason for the apparent failure of the tax treatment of depreciation to achieve its stated objective.

${ }^{1}$ Pub. Law 107-147, 116 Stat. 21

2 See Cohen and Cummins (2006), Edgerton (2009) and Knittel (2007)

2013 The Clute Institute http://www.cluteinstitute.com/ 


\section{THE TEXTBOOK TREATMENT OF THE EFFECT OF DEPRECIATION ON THE INCENTIVE TO UNDERTAKE NEW INVESTMENT}

Well-known (and well-regarded) textbooks in finance ignore the opportunity to explore how the cost-basis of the tax depreciation charge imparts a bias to the firm's incentive to invest in new capital goods. For example, the textbook by Brealey, Myers and Allen (2008) states on page 51:

Depreciation tax shields contribute to project cash flow, but they are not valued separately; they are just folded into project cash flows along with dozen, or hundreds, of other specific inflows or outflows.

Similarly, the textbook by Ross, Westerfield and Jaffe (2010) states on page 189:

We know that depreciation is a non-cash expense. The only cash flow effect of deducting depreciation is to reduce our taxes, a benefit to us.

Neither of the cited texts (or others that could be cited) addresses the question of how depreciation charges affect the firm's incentive to undertake new investments in depreciable capital goods in a period of significant inflation.

It is well understood that the purpose of the depreciation charge allowed by the taxing authority is to write off the cost of a depreciable asset that is used up in producing the income of the business. Even if wear, tear and obsolescence of equipment could be measured accurately, the funds accumulated in a depreciation reserve based on historical costs would not be adequate to maintain the value of the capital stock during periods of rising prices. The result is an overstatement of profits and, thus, some tax on the capital itself. That consequence cannot help but affect incentives for investment in long-lived capital goods in a period of inflation.

Contrary to the positions adumbrated in the texts cited above, this paper suggests that the cost-basis of depreciation charges for a contemplated investment in a new capital good may impart a strong disincentive to acquire the good if the business expects significant inflation during the depreciable life of the good.

\section{CAPITAL GOOD INVESTMENT IN A PERIOD OF INFLATION}

A fundamental proposition in corporate finance - a proposition found in virtually every college-level textbook on the subject - states that the incentive (or disincentive) to invest in a capital good is determined by the firm's expectation of the risk-adjusted discounted value of the after-tax net income ascribed to the investment. A tax policy that has the effect of diminishing the discounted value of after-tax net income generated by the asset likewise diminishes the incentive to acquire the asset. The analysis proceeds by examining how the tax treatment of depreciation affects the discounted value of after-tax net income.

Suppose the firm is contemplating an investment in a capital good at date $t=0$. The investment is expected to generate earnings in the business for $T$ successive discrete periods into the future. It is assumed the equipment has zero salvage value or resale value.

Let $I_{t}$ represent the real before-tax income that the firm expects the contemplated investment will generate in year $t$ (defined as the real cash flow expected before deductions for depreciation and taxes). In an economy of zero inflation, $I_{t}$ is calculated as sales revenue less all operating expenses and less interest on debt, if any.

It is assumed that the depreciation charged to the asset in year $t$ is calculated by applying any method permitted by the taxing authority. The annual depreciation charge is symbolized by $D_{t}$. Whatever method is chosen by the firm to calculate depreciation, it is assumed that the depreciation charge is not adjusted to reflect inflation's effect on the replacement cost of the capital good. Under current Federal corporate tax law, the firm's expectation of future inflation will not affect depreciation charges on the asset because its cost basis is fixed for tax purposes. After the asset is acquired, the depreciation charges are known with certainty and are unaffected by changes in the overall price index. ${ }^{3}$

${ }^{3}$ See VanHorne (1971, p. 655)and Motley (1969) 
It is assumed that the firm's real cost-of-capital is time-invariant and is symbolized by $r$, and it is assumed that the firm adjusts its real cost of capital to reflect the perceived riskiness of the cash flow stream generated by the contemplated investment.

Last, it is assumed that the firm's marginal effective tax rate is $\tau$ and is fixed with respect to the cash flows associated with the investment.

It is textbook wisdom that an investment in a capital good will be undertaken if the firm expects that the risk-adjusted discounted value of the after-tax net income ascribed to the investment exceeds zero. ${ }^{4}$ Beginning with that premise, we analyze how the discounted value of the after-tax income of the project varies with respect to inflation.

In an economy where inflation is expected to be zero over the depreciable life of the investment, its riskadjusted discounted value can be expressed as a function of the firm's marginal corporate income tax rate, as shown in equation (1):

$$
V(\tau)=\sum_{t=1}^{T} \frac{I_{t}-\tau\left(I_{t}-D_{t}\right)}{(1+r)^{t}}
$$

The firm forms an expectation of the annual rate of inflation over the depreciable life of the capital good. The expected annual rate is symbolized by $\theta$. It is assumed the expected annual rate of inflation is time-invariant.

To the extent that the firm expects inflation to affect the firm's sales revenues and its operating costs equally, the expected value of the nominal before-tax net income in year $t$ is $(1+\theta)^{t} I_{t}$.

The effective risk-adjusted nominal discount rate applied by the business is symbolized by $r_{n}$. It is calculated in equation (2):

$$
1+r_{n}=(1+\theta)(1+r)
$$

The firm's managers recognize that the calculation of the discounted value of the investment must be modified to reflect the effects of inflation. Thus, equation (1) is redefined as a bi-argument function expressed as equation (3) below.

$$
V(\tau, \theta)=\sum_{t=1}^{T} \frac{(1+\theta)^{t}(1-\tau) I_{t}+\tau D_{t}}{\left(1+r_{n}\right)^{t}}
$$

One can infer the effect on the investment incentive of an increase in expected inflation by taking the partial derivative of equation (3) with respect to $\theta$. The resulting equation is displayed in equation (4):

$$
\frac{\partial V(\tau, \theta)}{\partial \theta}=\frac{-\tau}{1+\theta} \sum_{t=1}^{T} \frac{t D_{t}}{\left(1+r_{n}\right)^{t}}<0
$$

The practical implication of equation (4) is summarized in Proposition 1.

\section{Proposition 1}

If the taxing authority requires depreciation charges to be based on the fixed cost of the capital good acquisition, the marginal incentive to undertake new investment in capital goods is a decreasing function of the firm's inflation expectations.

4 The theory developed in this paper assumes that capital rationing as a limiting factor on investment decisions does not apply. 


\section{MEASUREMENT OF THE EFFECT OF INFLATION ON THE INCENTIVE TO INVEST IN NEW CAPITAL GOODS}

Equation (3) can be exploited to analyze how the firm's incentive to undertake new investment at an arbitrary marginal tax rate compares to its incentive at a zero tax rate.

The baseline case is where the earnings of the corporation are not taxed. In that case, $\tau=0$. The riskadjusted discounted value of the corporation's after-tax earnings steam is calculated in equation (5).

$$
V(0, \theta)=\sum_{t=1}^{T}\left(\frac{1+\theta}{1+r_{n}}\right)^{t} I_{t}=\sum_{t=1}^{T} \frac{I_{t}}{(1+r)^{t}}
$$

The function $V(0, \theta)$ in equation (5) is the risk-adjusted real discounted value of the net income generated by the investment before depreciation and taxes. Notice that although expected inflation appears as a formal argument in the function, the absence of a depreciation tax shield renders its effect nugatory.

Equation (5) represents the obvious proposition that if inflation affects sales revenues and operating costs equally, before depreciation is charged against net income and before tax liability is deducted, the effective discount rate is the firm's real cost-of-capital. Thus, a marginal investment that will increase the before-tax value of the corporation is valued as the discounted value of the real cash flow expected before a charge for depreciation. This makes sense because charges for depreciation can be calculated pursuant to a variety of methods and all involve more-or-less arbitrary protocols designed to optimize the tax shield.

The baseline value function $V(0, \theta)$ can compare to its counterpart function when the corporation's nominal income is taxed and the corporation exploits its depreciation tax shield. Equation (3) can be rearranged to the expression in equation (6).

Define $\% \Delta V$ as the percentage difference between (a) the value of the corporation's contemplated investment if its net income after depreciation is taxed at a marginal rate $\tau$ and (b) the value of the corporation's investment income if it is not taxed:

$$
\% \Delta V=\frac{V(\tau, \theta)-V(0, \theta)}{V(0, \theta)}
$$

The numerical value of $\% \Delta V$ measures how the marginal corporate income tax rate will affect the incentive to undertake the contemplated investment in depreciable capital in a period of inflationary expectations. The Appendix reflects how $\% \Delta V$ can be calculated as equation (7).

$$
\% \Delta V=-\tau\left(1-\frac{1}{V(0, \theta)} \sum_{t=1}^{T} \frac{D_{t}}{\left(1+r_{n}\right)^{t}}\right)
$$

The summation term within the parentheses on the right side of equation (7) is the nominal discounted value of the depreciation tax shield based on historical cost represented as a percentage of the risk-adjusted real discounted value of the net income before depreciation charges and taxes. Notice that an increase in expected inflation reduces the discounted value of the depreciation tax shield but does not affect the real before-tax value of the investment. If the depreciation tax-shield is reduced, ceteris paribus, the incentive to invest is likewise reduced.

The practical implication of equation (7) is summarized in Proposition 2.

\section{Proposition 2}

If the business expects inflation over the depreciable life of a contemplated investment in a capital good, and if inflation is expected to affect the operating cash flows of revenues and costs equally, the nominal discount rate applied to the depreciation tax shield is greater than the effective discount rate applied to the income cash flow 
before depreciation and taxes. The result is to overstate taxable income and thus result in a marginal tax on the business' capital.

The practical implication of Proposition 2 is that a concurrence of inflationary expectations and historical cost depreciation diminish the incentive of the corporation to invest in a depreciable capital good, ceteris paribus. ${ }^{5}$

\section{CONCLUDING COMMENTS}

The analysis carried out in this paper has implications for tax policy. A tax policy designed to avoid the biasing effect of depreciation based on historical costs would allow firms to calculate depreciation charges after adjusting the historical costs for the increase(s) in the average of all prices. The result of the policy is that gains and losses on depreciable assets exceeding those that reflect changes in the general price level are included in income as they accrue.

An innovative idea of adjusting the system of tax depreciation for inflation is to allow an immediate deduction for the present value of the future economic depreciation that firms could claim if there were zero inflation. No adjustment for inflation would ever be needed because the depreciation charge would be taken in the same year in which the asset was purchased. The result of this approach is consistent with the result for inflationadjusted historical cost depreciation because gains from changes in the relative prices of depreciable assets would be included in income.

\section{AUTHOR INFORMATION}

Edmund H. Mantell was awarded a Bachelor's degree in Economics by the State University of New York (Oneonta.) He was awarded a Master's degree in Economics and a Ph.D. degree in Economics and Finance by the University of Pennsylvania. He has been employed as an officer in several large financial institutions. He currently holds an appointment as Professor of Finance and Economics at the Lubin School of Business, Pace University, New York. His main research interests are in the areas of decision making under uncertainty and the applications of economics to law. E-mail: EMantell@ pace.edu

\section{REFERENCES}

1. Brealey, R.A., S.C. Myers and F. Allen. Principles of Corporate Finance. $9^{\text {th }}$ ed. New York, N.Y., McGraw-Hill, 2008

2. Cohen, Darrel and Jason C. Cummins. A Retrospective Evaluation of the Effects of Temporary Partial Expensing. FEDS Working Paper Series, 2006 (19), 2006

3. Edgerton, Jesse. Taxes and Business investment: New Evidence From Used Equipment. Unpublished working paper, 2009

4. Investment Incentives and Corporate Tax Asymmetries, Federal Reserve Board, May 2010

5. Knittel, Matthew. Corporate response to accelerated tax depreciation for tax years 2002-2004. Office of tax Analysis Papers, 98, 2007

6. Motley, Brian Inflation and Common Stock Values: Comment. Journal of Finance, XXIV, (June 1969)

7. Ross, Stephen, Randolph Westerfield and Jeffrey Jaffe. Corporate Finance, $9^{\text {th }}$ ed., New York, N.Y., McGraw-Hill, 2010.

8. Van Horne, James C. A Note on Biases in Capital Budgeting Introduced by Inflation. The Journal of Financial and Quantitative Analysis, Vol. 6, No. 1 (Jan. 1971)

\footnotetext{
5 Accelerated depreciation methods based on historical costs, which are used in many countries, are often justified on inflation grounds, but they approximate direct adjustments for inflation only adventitiously. The ACRS system enacted in the United States is an example of a choice of depreciation method that was justified, in part, on the grounds of inflation.
} 


\section{APPENDIX}

Equation (3) can be resolved into its components as:

$$
\begin{gathered}
V(\tau, \theta)=\sum_{t=1}^{T} \frac{(1+\theta)^{t}(1-\tau) I_{t}+\tau D_{t}}{\left(1+r_{n}\right)^{t}} \\
=\sum_{t=1}^{T}\left(\frac{1+\theta}{1+r_{n}}\right)^{t} I_{t}-\tau\left[\sum_{t=1}^{T}\left(\frac{1+\theta}{1+r_{n}}\right)^{t} I_{t}-\sum_{t=1}^{T} \frac{D_{t}}{\left(1+r_{n}\right)^{t}}\right] \\
=\sum_{t=1}^{T} \frac{I_{t}}{(1+r)^{t}}-\tau\left[\sum_{t=1}^{T} \frac{I_{t}}{(1+r)^{t}}-\sum_{t=1}^{T} \frac{D_{t}}{\left(1+r_{n}\right)^{t}}\right]
\end{gathered}
$$

Equation (5) in the main body of the text defines $V(0, \theta)$. The definition can be substituted into the decomposition of equation (3) above to yield:

$$
V(\tau, \theta)=V(0, \theta)-\tau\left[V(0, \theta)-\sum_{t=1}^{T} \frac{D_{t}}{\left(1+r_{n}\right)^{t}}\right]
$$

Subtracting $V(0, \theta)$ from both sides of the equation and then dividing both sides by $V(0, \theta)$, the result appears as equation (7) in the text. 